\title{
MAP AGEBRA IN TOURISM POTENTIAL MODELLING FOR IMPROVING SOCIAL ISSUES IN MASARYK'S SCHOOL FOREST ENTERPRISE KŘTINY
}

\author{
Aleš RUDA ${ }^{1}$, Michaela POKLADNÍKOVÁi
}

DOI: $10.21163 / G T \_2016.111 .08$

\begin{abstract}
:
Considering actual economic situation tourism industry represents important part of many national incomes. Creating and opening tourism destinations go with the opportunity to make money, generate job opportunities attract investors etc. In both cases, mass tourism production and the support of local tourism opportunities identification of tourism potential is crucial. Many methods (qualitative and quantitative) and composite indicators have been developed within tourism potential identification to help decision makers to plan and manage human activities in the landscape. This paper brings not new but updated insight into using GIS analyses for different level of tourism potential identification. Presented case study is situated in Training Forest Enterprise Masaryk Forest Krrtiny, Czech Republic which must, within FSC policy (Forest Stewardship Council), also ensure beneficial social conditions inside managed area. Specific composite indicator for local territory was developed. Processed multicriterial analysis using spatial decision-making approaches (weighted sum method) enabled to count the value of tourism potential for each pixel within processed raster data format. Using equal interval reclassification algorithm five categories with different tourism potential value were set. Because of specific composite indicator proposal it is finally clear that small areas with prevailing forest function can offer many opportunities for tourism and recreation.
\end{abstract}

Key-words: Spatial decision making, Tourism potential, Map algebra, GIS, Expert modelling.

\section{INTRODUCTION}

Tourism is now an important source of income for both administrative regions, and the territory of the School Forest Enterprise Masaryk's Forest Křtiny (SFE MF Krrtiny) not only in the Czech Republic but worldwide. SFE MF Krrtiny currently focuses primarily on maintaining the quality of the environment and management of its vast forest area, but in the context of compliance with the standards of the FSC (Forest Stewardship Council) also strives to meet social sustainability standards. Approximately a one third of the territory of SFE MF Krrtiny is occupied by the Moravian Karst, which can make it very attractive for potential visitors. For the needs of tourism development, it is necessary to analyse the territory as a complex area and to include all potential elements of tourist attractions. Detection and identification of tourism development potential is a key step for its further development. Natural and cultural-historical potential of the territory may become a major source of the revenue for SFE MF Krrtiny, through which it can continue to spread awareness of their existence and possible tourist activities, organizing cultural events and to implement further development projects. The increasing number of visitors and new possibilities of development of tourism activities in the territory can finally be used for its and municipalities development located in the region.

\footnotetext{
${ }^{1}$ Mendel University, 61300 Brno, Czech Republic, ruda@node.mendelu.cz.
} 


\section{POTENTIAL OF TOURISM DEVELOPMENT}

At present there is no uniform definition of tourism potential, primarily because it is a notion so broad that it cannot be simplified without being discredited by some of components being an essential part of its importance. Glăvan (1996) sees the potential of tourism as a set of natural, cultural, historical, social, demographic, technological and economical components that are scientifically evaluated, proved in practice and can be used in tourism. Krippendorf (1980) explains it more broadly as a complex of tangible and intangible elements meeting the needs of tourists and giving them some benefit. Pásková and Zelenka (2002) define the potential of tourism as the aggregated value of all assumptions of tourism awarded based on a scoring scale and reduced by the negative value of negative factors in tourism development. Pásková (2014) then understands the potential of areas for tourism implementation and development as the ability of primary sources to attract a certain number of visitors going hand in hand with promotion of tourism development. GIS applications range encompassing tourism suitability mapping (also called as tourism potential identification or territorial capital assessment within tourism sector) have appeared in the 80 s of the $20^{\text {th }}$ century based on McHarg (1969) work and automated with the development of computer cartography (Lyle \& Stutz, 1983). This approach has also been used for GIS-based methodologies applied in land use planning. The first GIS-integrated concept of recreation suitability index was developed by Levinsohn et al (1987) although Kliskey (2000) mentioned Duffield and Coppock (1975) computer based delineation of recreational landscapes as the first effort working with spatial representations. The index covered a number of variables starting from topography features, land cover attributes and ending with accessibility features to destination area. More inventorying is approach of Gobster, Gimblett and Kelley (1987) focused on finding recreation opportunities using physical, social and managerial variables. Compared to above mentioned approaches connected mostly with nature environment Bína (2010) and Ruda (2010) proposed tourism potential based on all necessary components comprising localization (natural and culture-historical factors) and realization (usability and accessibility factors) assumptions. Bína (2010) defines two types of tourism potential assumptions - localization and realization. Localization assumptions are made of natural and cultural-historical components and realization assumptions include the accessibility and usability of the territory in tourism development. Bína (2010) revised methodology is based on a complex conditions of tourist attractions and can be understood in three forms: as the suitability of area for a particular tourist activity, genius loci, that exists in the area and is attractive for visitors, and a major cultural or sports events being held in the area. Individual components of localization assumptions are than divided into two subsystems - natural and cultural-historical. Individual components of localization assumptions are given scores and weighted according to expert estimation. Realization assumptions are according to Bína (2010) assigned less importance, nevertheless he admits that in certain cases compared to localization assumptions they might be more significant. A certain disadvantage of methodology above is its application in administrative regions and austerity of calculation in lower than local level (Ruda, 2010). Both localization and realization assumptions together create an overall tourism potential in the area and are consistently considered as factors of tourism development. In terms of tourism potential development, Hrala (2002) gives localization assumptions less importance but he also admits that the localization of tourism activities is crucial regardless they are natural or cultural-historical origin. In the view of assessing tourism potential both approaches qualitative and quantitative can be found. In case of spatial decision-making quantitative approach is more significant 
especially in combination with GIS tools and geostatistical modelling. Prevailing method of quantitative assessment of tourism potential is to design a wide range of composite indicators implementing variously configured weights (Ruda, 2014). Vystoupil et al (2006) are particularly interested in theoretical-methodological and practical approaches for tourism regionalization. On the example of South Moravian Region Klapka, Nováková and Frantál (2008) assess tourism potential when adopting methodology of natural potential for cultural-historical potential assessment. However, they face a problem of different expression of these two sub-potentials. While the natural potential is mainly illustrated by polygons, cultural-historical potential is mostly represented by points. Using the interaction potential based on spatial interaction models and the principles of Newton gravity model they transform point features of cultural-historical potential to polygon features. The need of spatial analysis with tourism assessment was also proved by using GPS (Bernadóa et al, 2013). Mikulec and Antoušková (2011) used GIS methods for tourism potential assessment and came out from Bína (2010) methodology, which can be found in many works devoted to tourism potential assessment (eg. Ruda, 2014). Experts in regional development are also interested in the relationship between tourism and the environment, and so it is appropriate to give special attention to the discussion and implementation of sustainable tourism development especially when the attention has increased with obvious effects of mass tourism on the environment of target destinations (Butler, 1999). Coccossis (1996) argues that there are at least four ways how to interpret tourism in context of sustainable development areas: (1) as the economic stability of the sector, (2) a need to minimize the impact on the environment, (3) as a long-term prosperity and longevity of the territory and (4) as a strategy for sustainable development of natural and social environment. Sharpley (2000) suggests that the interpretation of sustainable tourism and sustainability is difficult and cannot be so easily transferred to tourism industry. The very concept of sustainable tourism is difficult to define because there is a number of different understanding supported by scientists' assurances that their definition is the most appropriate. For example, Butler $(1993,1999)$ describes sustainable tourism as a form of tourism that develops in such a way that ensures a long-term viability, minimal disturbances in the environment while successfully developing of destination area. Clarke (1997) therefore argues that it is essential to work with the concept of sustainable tourism as an evolving organism, which decreases fragmentation of its definition.

\section{DATA, METHODOLOGY AND PROCESSING}

The aim of the study was to identify tourism development potential in SFE MF Krrtiny. This was achieved by proposal of composite indicator, database building and geostatistical processing in the geographical information system (GIS). Considering connectivity and continuity of all features within tourism industry calculations were extended $2 \mathrm{~km}$ beyond the study area border in order to get clearer image of neighbouring area.

The basic data used to identify tourism potential comes from several different sources. Topographic data was used from ZABAGED (Fundamental base of geographic data) dataset produced by Czech Office for Surveying, Mapping and Cadastre (Č́ZZK). It included 12 map sheets at a scale of 1: 10000 covering the area of SFE MF Krrtiny with its surroundings defined as two-kilometre buffer along the study area. Supplementary thematic data was taken from the database managed by the Faculty of Forestry and Wood Technology, Mendel University in Brno. But most of specific thematic data was collected directly in the study area for which a mapping device Trimble Geo 5T TM was used. All 
data were processed and analysed in ArcGIS 10.3 for Desktop (Esri production). The original vector data format was converted to a raster data format (grid) with a pixel resolution of $100 \mathrm{~m}$ and $250 \mathrm{~m}$, which in the case of unclear details documents the distribution of chosen phenomenon at smaller scale.

The proposal of final composite indicator was based on the determination of localization and realization assumptions (sub-indicators) including equally weighted components (eg. natural and cultural-historical potential) and their partial indicators (Table 1). A key approach of quantitative assessment was to identify polygon, polyline or point occurrence of partial phenomenon (Pokladníková, 2015). In case of polygon features, their proportion (in percent) in the reference unit was considered. Length of linear features were recalculated on the area of reference unit and in case of point features, their occurrence, number or quality was assessed. Measured values of polygonal and linear features were analysed for variation range and then using equal intervals algorithm reclassified into five classes. The highest value represents the highest density of feature occurrence. Five-point scale, where zero means no occurrence of feature represents the mechanism of scoring. Point features were evaluated on the basis of an expert estimation coming from a questionnaire survey. Techniques of spatial decision-making, namely Weighted sum method was used to compute the final value of composite indicator. At the level of individual components of partial sub-indicators assigned values were multiplied by the appropriate derived weight, summed and scored according to mentioned algorithm. The same was processed at the level of sub-indicators.

Table 1. Structure of composite indicator for tourism potential development, own proposal.

\begin{tabular}{|c|c|c|c|}
\hline \multicolumn{2}{|c|}{ LOCALIZATION ASSUMPTIONS } & \multicolumn{2}{|c|}{ REALIZATION ASSUMPTIONS } \\
\hline NATURAL & $\begin{array}{l}\text { CULTURAL- } \\
\text { HISTORICAL }\end{array}$ & USABILITY & $\begin{array}{l}\text { ACCESSIBILIT } \\
\mathrm{Y} \\
\end{array}$ \\
\hline arboretum & castle & shop & bus stop \\
\hline protected landscape area & playing field & information office & other way \\
\hline cave & horsemanship & catering service & cycle path \\
\hline swimming pool & cross and calvary & $\begin{array}{c}\text { accomodation } \\
\text { facilities } \\
\end{array}$ & road \\
\hline forest & cultural event & & tourist trail \\
\hline quarry & forest pantheon & & railway station \\
\hline lookout point & museum & & \\
\hline $\begin{array}{c}\text { small protected landscape } \\
\text { area }\end{array}$ & place of pilgrimage & & \\
\hline educational trail & sacral building & & \\
\hline river sinking & special sport places & & \\
\hline abyss & sport event & & \\
\hline rock formation & palace & & \\
\hline spring & & & \\
\hline water course & & & \\
\hline memorial tree & & & \\
\hline
\end{tabular}


Summed values were reclassified into five classes and linguistically named (very low low - medium - high - very high potential). Respecting composite indicator proposal, final value of tourism potential is based on the sum of both sub-indicators. In this step, Natural break classification algorithm was used to group classes with similar tourism potential values of the same linguistic variables as mentioned above. For all mentioned calculations map algebra was used. Table 1 documents individual components of tourism potential.

Within the design of composite indicator those attributes which would present duplication were excluded from the original proposal. In the case of cross-comparison by calculating the correlation coefficient, among the attributes of composite indicator there were no significant correlation dependencies that would eliminate their participation in assessing procedure.

\subsection{Point features assessment}

Each point layer has its certain specifics and therefore it was necessary to compile the scoring range for each layer separately. Scoring was inspired by Bína (2010) and Ruda (2014) methodology for tourism potential assessment. Since the area of SFE MF Krrtiny counts a few attributes assessed in mentioned methodology it was necessary to compile the scoring scales based on a questionnaire survey identifying the attractiveness for potential tourists which on the other hand might be more or less subjective. The criterion for evaluation of bus stops (b.s.) was the number of bus stops in partial reference units (1 b.s. 1 point, 2 b.s. - 3 points, 3 and more b.s. - 5 points). Castles were evaluated according to their current state or how they are used (indistinct ruins - 1 point, castle ruins - 3 points, castle in operation - 5 points). The criteria for playing field evaluating were the number of objects in different reference units, their type and way of use (1 undistinguished playing field - 1 point, playground - 2 points, 2 and more playing fields - 3 points, a tennis court / sport complex - 5 points). Information centres are very important for tourism, therefore each reference unit in which the centre is located 5 points were assigned. Caves are evaluated like playing fields according to several aspects (significant crack in the rock or 1 cave - 1 point, 2 and more caves - 3 points, cave in operation - 5 points). In the case of swimming pools it is understood that each reference unit can have only one swimming pool. Points are assigned according to the type of pool (natural water reservoir, pond - 1 point, built-up swimming pool - 3 points, swimming pool, indoor swimming pool - 5 points). Cross and calvary were evaluated according to their number in each reference unit ( 1 time - 1 point, 2 times - 3 points, 3 times and more - 5 points). In case of cultural events, all reference units, which belong to the area where these events take place are evaluated. Organizing these events significantly increases the tourism potential of destination area, therefore five points were identically assigned. In the study area there are several lookout towers and a number of lookout points. Reference units were evaluated according to the importance for tourism (lookout point - 3 points, lookout tower - 5 points). Forest pantheon (FP) is also very famous for SFE MF Krrtiny. The number of occurrence of FP was a key for scoring (1 time - 1 point, 2 times - 3 points, 3 times and more - 5 points). Scoring of museums was determined by the occurrence ( 5 points) or absence ( 0 points) of features in the reference unit. In case of shops a way of scoring was similar to museums and information centres. The only difference was smaller number of assigning points, three points were assigned. Places of pilgrimage were evaluated the same way as cultural events. Therefore, all reference units indicating this place were assigned five points. River sinking is an essential part of SFE MF Krrtiny. In the study area their presence is rare but very important and attractive for tourists. Scoring of this attribute was determined only by its 
occurrence ( 5 points) or absence ( 0 points). Abyss is a natural part of many karst areas. Landscape protected area Moravian Karst, famous for its karst objects, extends also to study area. Although their occurrence is also rare in study area some karst object can be found and also presented on information boards. Therefore five points were assigned for the occurrence of significant abyss, in case of major depression in the ground of similar parameters as abyss three points were assigned. Whereas the sacral buildings are represented by one example in each reference unit in case of church three points were given and in case of monastery five points were assigned. Sport events are also represented by their organizing on sport areas which are more unique and exceptional to be included within playing fields. Therefore, the reference units with identified features were evaluated based on their importance for tourists (mini-golf, baseball field, sport hall - 1 point, a climbing centre - 3 points, motocross area - 5 points. If a given reference unit is located in a regularly sport event hotspot one point was assigned. The same rule was applied for memorial trees, but in case of group of memorial trees identification two points were given to each reference unit. The presence of catering service was scored based on the number in each reference units ( 1 time - 1 point, 2 times - 3 points, 3 times and more - 5 points). Due to the relatively small importance of wells and springs for the final value of tourism potential their number was important for evaluating (1 time - 1 point, 2 times and more - 3 points). Accommodation was scored according to its type which is related to the level of comfort and service that can be offered by individual accommodation providers (hostel - 1 point, camping site - 2 points, boarding house - 3 points, hotel - 5 points). Castles belong among significant cultural objects. The presence of a castle in operation was scored five points, in case of castle without operation three points were assigned. In terms of sustainable tourism development, railway stations were considered as more important than bus stops, therefore five points were assigned for their occurrence in each reference unit.

\subsection{Linear features assessment}

Table 2. Linear features assessment.

\begin{tabular}{|c|c|c|c|}
\hline points & other ways & cyclo paths & educational trails \\
\hline $1 \mathrm{p}$ & $\left(0 ; 8,1708 \times 10^{-3} \mathrm{~m}>\right.$ & $\left(0 ; 6,0412 \times 10^{-3} \mathrm{~m}>\right.$ & $\left(0 ; 5,0554 \times 10^{-3} \mathrm{~m}>\right.$ \\
\hline $2 \mathrm{p}$ & $\begin{array}{c}\left(8,1708 \times 10^{-3} ; 1,63376 \times 10^{-2}\right. \\
m>\end{array}$ & $\begin{array}{c}\left(6,0412 \times 10^{-3} ; 1,20574 \times 10^{-2}\right. \\
\mathrm{m}>\end{array}$ & $\begin{array}{c}\left(5,0554 \times 10^{-3} ; 1,00548 \times 10^{-2}\right. \\
m>\end{array}$ \\
\hline $3 \mathrm{p}$ & $\begin{array}{c}\left(1,63376 \times 10^{-2} ; 2,45044 \times 10^{-2}\right. \\
m>\end{array}$ & $\begin{array}{c}\left(1,20574 \times 10^{-2} ; 1,80736 \times 10^{-2}\right. \\
\mathrm{m}>\end{array}$ & $\begin{array}{c}\left(1,00548 \times 10^{-2} ; 1,50542 \times 10^{-2}\right. \\
\mathrm{m}>\end{array}$ \\
\hline $4 \mathrm{p}$ & $\begin{array}{c}\left(2,45044 \times 10^{-2} ; 3,26712 \times 10^{-2}\right. \\
m>\end{array}$ & $\begin{array}{c}\left(1,80736 \times 10^{-2} ; 2,40898 \times 10^{-2}\right. \\
m>\end{array}$ & $\begin{array}{c}\left(1,50542 \times 10^{-2} ; 2,00536 \times 10^{-2}\right. \\
m>\end{array}$ \\
\hline $5 \mathrm{p}$ & $\begin{array}{c}\left(3,26712 \times 10^{-2} ; 4,0838 \times 10^{-2}\right. \\
\mathrm{m}>\end{array}$ & $\begin{array}{c}\left(2,40898 \times 10^{-2} ; 3,0106 \times 10^{-2}\right. \\
m>\end{array}$ & $\begin{array}{c}\left(2,00536 \times 10^{-2} ; 2,5053 \times 10^{-2}\right. \\
\mathrm{m}>\end{array}$ \\
\hline points & roads & tourist trails & water courses \\
\hline $1 \mathrm{p}$ & $\left(0 ; 8,9578 \times 10^{-3} \mathrm{~m}>\right.$ & $\left(0 ; 7,4756 \times 10^{-3} \mathrm{~m}>\right.$ & $\left(0 ; 4,0944 \times 10^{-3} \mathrm{~m}>\right.$ \\
\hline $2 \mathrm{p}$ & $\begin{array}{c}\left(8,9578 \times 10^{-3} ; 1,79146 \times 10^{-2}\right. \\
\mathrm{m}>\end{array}$ & $\begin{array}{c}\left(7,4756 \times 10^{-3} ; 1,49402 \times 10^{-2}\right. \\
\mathrm{m}>\end{array}$ & $\begin{array}{c}\left(4,0944 \times 10^{-3} ; 8,1798 \times 10^{-3}\right. \\
m>\end{array}$ \\
\hline $3 \mathrm{p}$ & $\begin{array}{c}\left(1,79146 \times 10^{-2} ; 2,68714 \times 10^{-2}\right. \\
\mathrm{m}>\end{array}$ & $\begin{array}{c}\left(1,49402 \times 10^{-2} ; 2,24048 \times 10^{-2}\right. \\
\mathrm{m}>\end{array}$ & $\begin{array}{c}\left(8,1798 \times 10^{-3} ; 1,22652 \times 10^{-2}\right. \\
\mathrm{m}>\end{array}$ \\
\hline $4 \mathrm{p}$ & $\begin{array}{c}\left(2,68714 \times 10^{-2} ; 3,58282 \times 10^{-2}\right. \\
m>\end{array}$ & $\begin{array}{c}\left(2,24048 \times 10^{-2} ; 2,98694 \times 10^{-2}\right. \\
\mathrm{m}>\end{array}$ & $\begin{array}{c}\left(1,22652 \times 10^{-2} ; 1,63506 \times 10^{-2}\right. \\
\mathrm{m}>\end{array}$ \\
\hline $5 \mathrm{p}$ & $\begin{array}{c}\left(3,58282 \times 10^{-2} ; 4,4785 \times 10^{-2}\right. \\
m>\end{array}$ & $\begin{array}{c}\left(2,98694 \times 10^{-2} ; 3,7334 \times 10^{-2}\right. \\
\mathrm{m}>\end{array}$ & $\begin{array}{c}\left(1,63506 \times 10^{-2} ; 2,0436 \times 10^{-2}\right. \\
\mathrm{m}>\end{array}$ \\
\hline
\end{tabular}


The criterion for scoring of line elements was their density, in this case, measured in meters on the area of the reference entity. Each linear feature has proposed its own scoring range, which would prevent from advantages in the reference units represented by denser occurrence. For all features five intervals of the same width were set (Table 2).

\subsection{Polygonal features assessment}

Polygonal features were scored based on their percentage occurrence in the reference units (Table 3). An exception in the evaluation was an indicator illustrating land use of SFE MF Krrtiny area. Given that every reference unit is covered by forests, built-up areas or other areas, the individual reference unit was scored depending on the largest area. The highest score ( 5 points) has forest areas followed by other areas ( 3 points) with fields, meadows and pastures. The lowest score (1 point) was given to built-up areas which in the terms of realization of tourism include the least attractive territories.

Table 3. Polygonal features assessment.

\begin{tabular}{|l|c|c|c|c|c|c|}
\hline percentage occurence $(\%)$ & $\langle 0\rangle$ & $(0,20\rangle$ & $(20,40\rangle$ & $(40,60\rangle$ & $(60,80\rangle$ & $(80,100\rangle$ \\
\hline points & $0 \mathrm{p}$ & $1 \mathrm{p}$ & $2 \mathrm{p}$ & $3 \mathrm{p}$ & $4 \mathrm{p}$ & $5 \mathrm{p}$ \\
\hline
\end{tabular}

\section{SCHOOL FOREST ENTERPRISE MASARYK'S FORST KŘTINY}

SFE MF Křtiny (Fig. 1) has of an area of 10492 ha and extends from northern edge of Brno city to Blansko between 210 and 575 metres above the sea level. It was established in 1923 when it was under the name School forestry farm Adamov given by the Ministry of Agriculture to former University of Agricultural in Brno (now Mendel University in Brno) as a school and experimental forestry area. Honorary title Masaryk Forest Krrtiny was awarded in 1932 by the Ministry of Agriculture with the approval of the first president of Czechoslovakia Tomas Garrigue Masaryk. Today it is an organizational part of Mendel University in Brno and serves as a purpose-built facility for all faculties especially for the Faculty of Forestry and Wood technology and:

- provides convenient facilities for research and results verification for students and teachers working in forestry, wood and landscape management,

- ensures the proper management of forest university property,

- offers public superior recreational facilities and especially attractive natural wealth.

Almost the entire area is covered by forests (Fig. 2). The bedrock consists mainly of granodiorite and greywacke but also limestone because one third of the area is situated in the Moravian Karst. The terrain is formed by deep valleys and glens mainly along the river Svitava and Krrtinský potok. The area is dominated by mixed forest in 4 forest vegetation zones. Most represented species are spruce, pine, larch, oak and beech. SFE MF Krrtiny has been using its natural potential for implementation of aesthetic and educational functions of forest. Natural wealth continues to grow to be preserved for present and future generations. A number of interesting tourist objects and places (maintained ridge with lookout points), glades within contiguous forest area bordered by exotic trees but also many historically and culturally significant sites have been also established here(slpkrtiny.cz, 2008). 


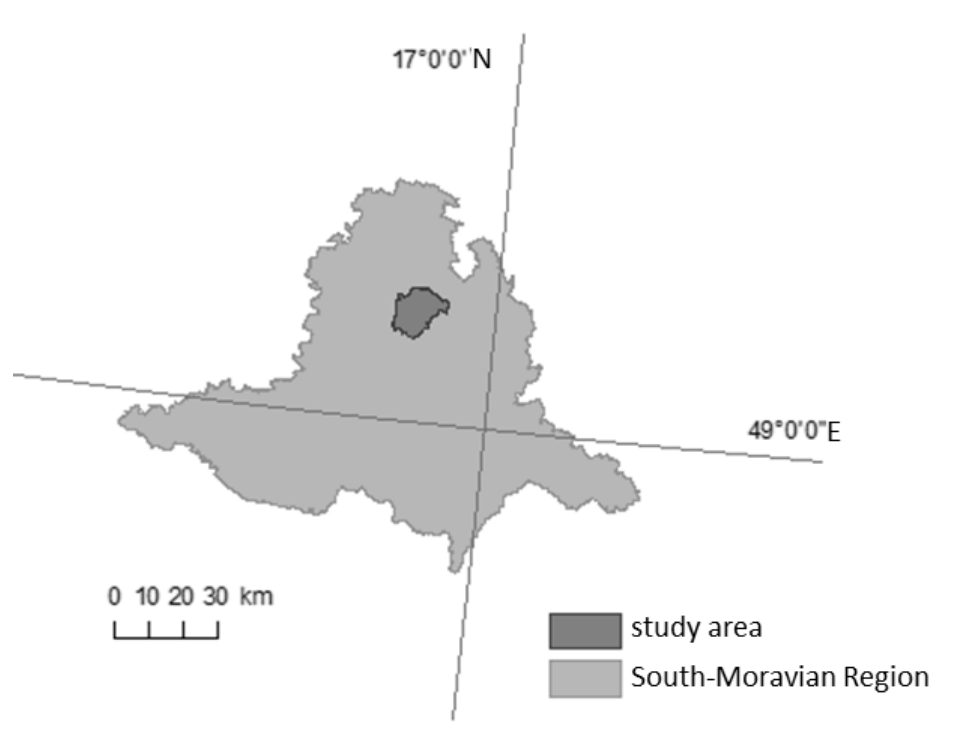

Fig. 1 Location of SFE MF Krrtiny in the South-Moravian Region.

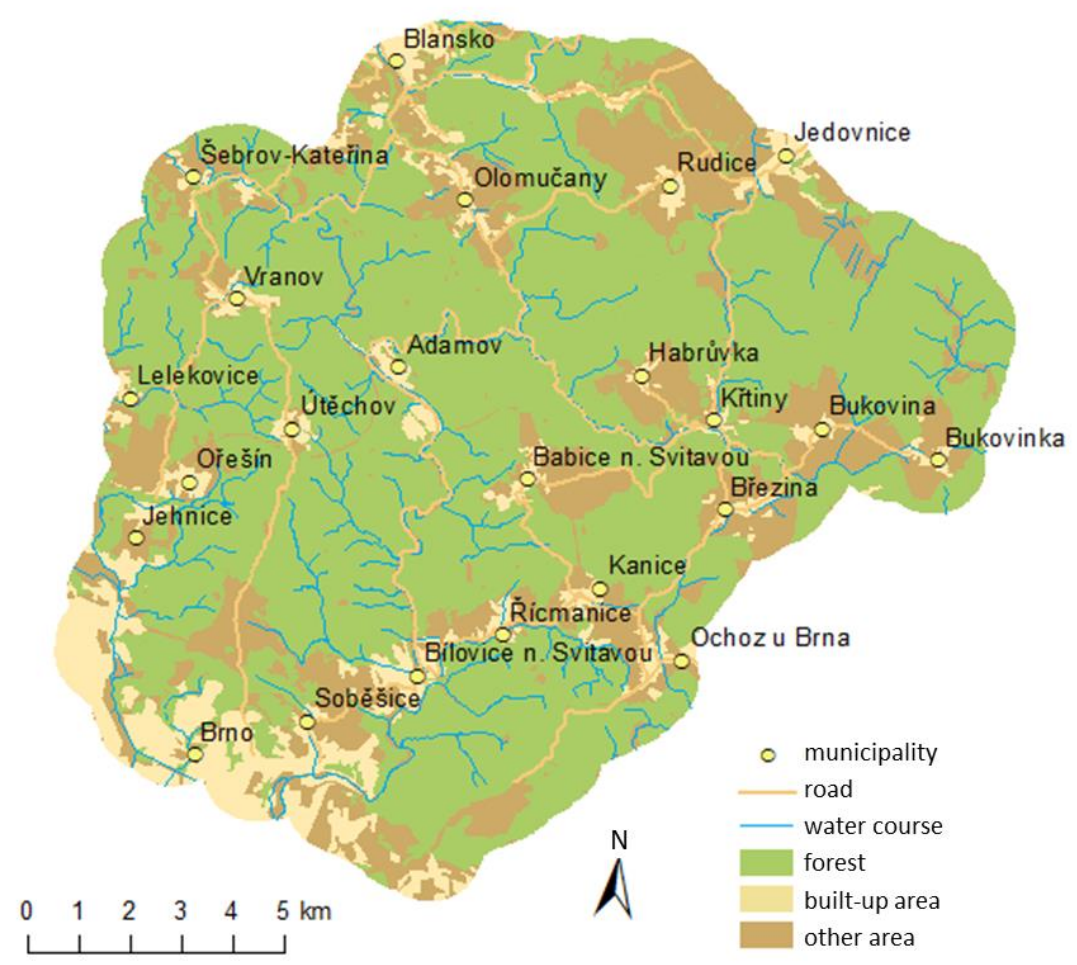

Fig. 2 Extended study area of SFE MF Křtiny. 


\section{TOURISM POTENTIAL COMPOSITION}

\subsection{Natural potential}

Determination of natural potential component counts 15 attributes (Table 1) whose preferences were set by Saaty pair weighted comparison (see Table 4). Although one might assume that the natural potential of the area covered by forests and other natural attractions will significantly outweigh the importance of other components it is not correct. Much of the study area illustrates very low natural potential (Fig. 3). The Moravian Karst is an important attribute significantly increasing the value for a substantial part of the destination area. Inside the protected landscape area it is possible to find places with high or even very high potential. These include mainly Blansko, Adamov, Jedovnice and Bílovice nad Svitavou where significant natural attractions are located.

Table 4. Saaty matrix for weights setting within Natural potential indicators.

\begin{tabular}{|c|c|c|c|c|c|c|c|c|c|c|c|c|c|c|c|c|c|}
\hline & 1 & 2 & 3 & 4 & 5 & 6 & 7 & 8 & 9 & 10 & 11 & 12 & 13 & 14 & 15 & GM & WGM \\
\hline 1 & 1 & 2 & 2 & 2 & 2 & 3 & 2 & 2 & 2 & 2 & 2 & 4 & 4 & 4 & 4 & 2,3603 & 0,1382 \\
\hline 2 & $1 / 2$ & 1 & 2 & 2 & 2 & 3 & 2 & 3 & 3 & 3 & 3 & 3 & 3 & 3 & 3 & 2,2206 & 0,13 \\
\hline 3 & $1 / 2$ & $1 / 2$ & 1 & 2 & 3 & 3 & $1 / 2$ & $1 / 2$ & $1 / 3$ & $1 / 2$ & 3 & 2 & 3 & 3 & 3 & 1,2556 & 0,0735 \\
\hline 4 & $1 / 2$ & $1 / 2$ & $1 / 2$ & 1 & 2 & 3 & $1 / 3$ & $1 / 2$ & $1 / 3$ & $1 / 2$ & 3 & 3 & 3 & 3 & 3 & 1,1142 & 0,0652 \\
\hline 5 & $1 / 2$ & $1 / 2$ & $1 / 3$ & $1 / 2$ & 1 & 2 & $1 / 3$ & $1 / 2$ & 3 & 3 & 3 & 2 & 2 & 5 & $1 / 2$ & 1,0921 & 0,0639 \\
\hline 6 & $1 / 3$ & $1 / 3$ & $1 / 3$ & $1 / 3$ & $1 / 2$ & 1 & $1 / 3$ & $1 / 3$ & 2 & 2 & 2 & $1 / 2$ & 2 & 2 & $1 / 2$ & 0,7068 & 0,0414 \\
\hline 7 & $1 / 2$ & $1 / 2$ & 2 & 3 & 3 & 3 & 1 & 2 & 3 & 3 & 3 & 3 & 3 & 3 & 3 & 2,0801 & 0,1218 \\
\hline 8 & $1 / 2$ & $1 / 3$ & 2 & 2 & 2 & 3 & $1 / 2$ & 1 & 3 & 3 & 3 & 2 & 2 & 2 & 2 & 1,3928 & 0,0815 \\
\hline 9 & $1 / 2$ & $1 / 3$ & 3 & 3 & $1 / 3$ & $1 / 2$ & $1 / 3$ & $1 / 3$ & 1 & 2 & 3 & 2 & 3 & 3 & 3 & 1,1578 & 0,0678 \\
\hline 10 & $1 / 2$ & $1 / 3$ & 2 & 2 & $1 / 3$ & $1 / 2$ & $1 / 3$ & $1 / 3$ & $1 / 2$ & 1 & 3 & 2 & 2 & 3 & 3 & 0,9733 & 0,0570 \\
\hline 11 & $1 / 2$ & $1 / 3$ & $1 / 3$ & $1 / 3$ & $1 / 3$ & $1 / 2$ & $1 / 3$ & $1 / 3$ & $1 / 3$ & $1 / 3$ & 1 & $1 / 2$ & $1 / 2$ & 3 & $1 / 3$ & 0,4503 & 0,0264 \\
\hline 12 & $1 / 4$ & $1 / 3$ & $1 / 2$ & $1 / 3$ & $1 / 2$ & 2 & $1 / 3$ & $1 / 2$ & $1 / 2$ & $1 / 2$ & 2 & 1 & $1 / 3$ & 2 & $1 / 3$ & 0,5255 & 0,0308 \\
\hline 13 & $1 / 4$ & $1 / 3$ & $1 / 3$ & $1 / 3$ & $1 / 2$ & $1 / 2$ & $1 / 3$ & $1 / 2$ & $1 / 3$ & $1 / 2$ & 2 & 3 & 1 & 2 & $1 / 2$ & 0,5921 & 0,0347 \\
\hline 14 & $1 / 4$ & $1 / 3$ & $1 / 3$ & $1 / 3$ & $1 / 5$ & $1 / 2$ & $1 / 3$ & $1 / 2$ & $1 / 3$ & $1 / 3$ & $1 / 3$ & $1 / 2$ & $1 / 2$ & 1 & $1 / 3$ & 0,3564 & 0,0209 \\
\hline 15 & $1 / 4$ & $1 / 3$ & $1 / 3$ & $1 / 3$ & 2 & 2 & $1 / 3$ & $1 / 2$ & $1 / 3$ & $1 / 3$ & 3 & 3 & 2 & 3 & 1 & 0,8027 & 0,047 \\
\hline & & & & & & & & & & & & & & & & 17,0807 & 1 \\
\hline & & & & & & & & & & & & & & & & \multicolumn{2}{|c|}{$\begin{array}{l}\lambda \max = \\
16,6931\end{array}$} \\
\hline
\end{tabular}

Legend: 1 -arboretum, 2 - protected landscape area, 3 -cave, 4 - swimming pool, 5 - land use, 6 - querry, 7 small protected landscape area, 8 - educational trail, 9 - river sinking, 10 - abbys, 11 - lookout point, 12 - rock formation, 13 - memorial tree, 14 - spring, 15 -water courses; GM-geometrical mean, WGM-weighted geometrical mean. 

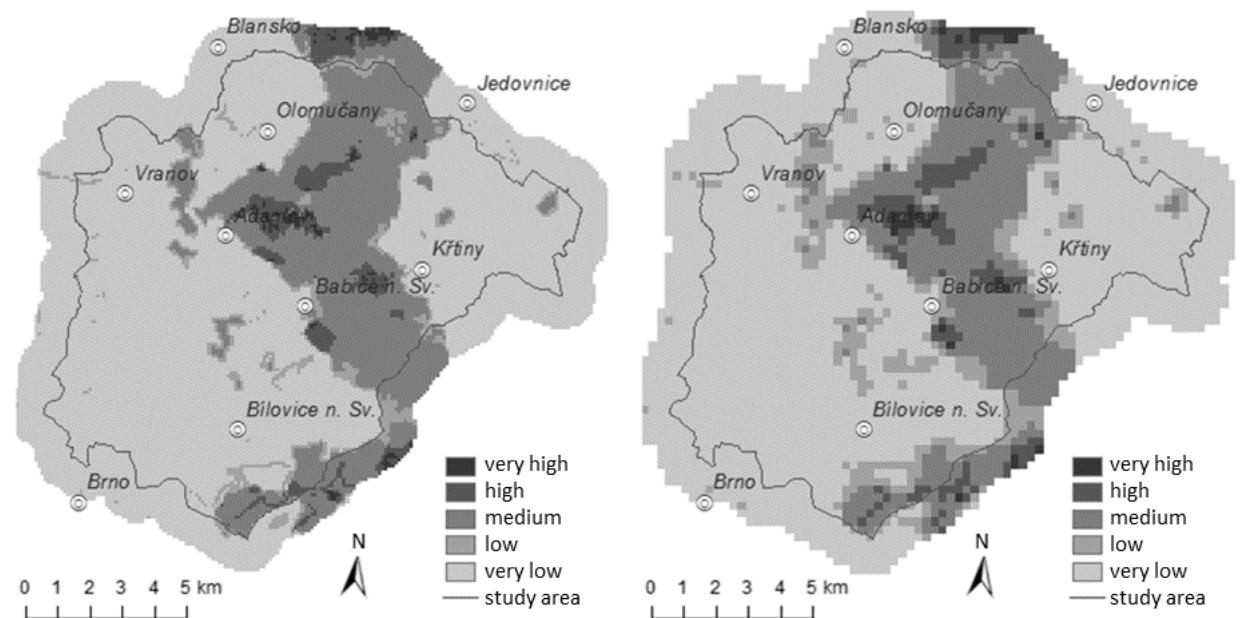

Fig. 3. Natural potential (left - grid with $100 \mathrm{~m}$ resolution, right - grid with $250 \mathrm{~m}$ resolution).

\subsection{Cultural-historical potential}

Cultural-historical potential component included 12 indicators (Table 1) and their preferences were given by weights (Table 5).

Table 5. Saaty matrix for weights setting within Cultural-historical potential indicators.

\begin{tabular}{|c|c|c|c|c|c|c|c|c|c|c|c|c|c|c|}
\hline & 1 & 2 & 3 & 4 & 5 & 6 & 7 & 8 & 9 & 10 & 11 & 12 & GM & WGM \\
\hline 1 & 1 & 7 & 5 & 5 & 5 & $1 / 2$ & 2 & $1 / 2$ & 4 & 2 & $1 / 2$ & $1 / 3$ & 1,7002 & 0,1068 \\
\hline 2 & $1 / 7$ & 1 & $1 / 2$ & $1 / 3$ & 2 & $1 / 5$ & $1 / 4$ & $1 / 5$ & $1 / 4$ & $1 / 3$ & $1 / 5$ & $1 / 6$ & 0,3237 & 0,0203 \\
\hline 3 & $1 / 5$ & 2 & 1 & $1 / 2$ & 2 & $1 / 5$ & $1 / 3$ & $1 / 5$ & $1 / 3$ & 2 & $1 / 5$ & $1 / 4$ & 0,487 & 0,0306 \\
\hline 4 & $1 / 5$ & 3 & 2 & 1 & 4 & $1 / 5$ & $1 / 3$ & $1 / 3$ & 3 & 2 & $1 / 3$ & $1 / 4$ & 0,7833 & 0,0492 \\
\hline 5 & $1 / 5$ & $1 / 2$ & $1 / 2$ & $1 / 4$ & 1 & $1 / 5$ & $1 / 4$ & $1 / 5$ & $1 / 4$ & $1 / 4$ & $1 / 7$ & $1 / 6$ & 0,2749 & 0,0173 \\
\hline 6 & 2 & 5 & 5 & 5 & 5 & 1 & 3 & 2 & 5 & 2 & 2 & 2 & 2,8604 & 0,1798 \\
\hline 7 & $1 / 2$ & 4 & 3 & 3 & 4 & $1 / 3$ & 1 & $1 / 3$ & 5 & 4 & $1 / 3$ & $1 / 4$ & 1,2409 & 0,078 \\
\hline 8 & 2 & 5 & 5 & 3 & 5 & $1 / 2$ & 3 & 1 & 5 & 2 & $1 / 2$ & 2 & 2,1757 & 0,1367 \\
\hline 9 & $1 / 4$ & 4 & 3 & $1 / 3$ & 4 & $1 / 5$ & $1 / 5$ & $1 / 5$ & 1 & $1 / 3$ & $1 / 4$ & $1 / 6$ & 0,5256 & 0,033 \\
\hline 10 & $1 / 2$ & 3 & $1 / 2$ & $1 / 2$ & 4 & $1 / 2$ & $1 / 4$ & $1 / 2$ & 3 & 1 & $1 / 2$ & $1 / 5$ & 0,7426 & 0,0467 \\
\hline 11 & 2 & 5 & 5 & 3 & 7 & $1 / 2$ & 3 & 2 & 4 & 2 & 1 & 2 & 2,4653 & 0,1549 \\
\hline 12 & 3 & 6 & 4 & 4 & 6 & $1 / 2$ & 4 & $1 / 2$ & 6 & 5 & $1 / 2$ & 1 & 2,3324 & 0,1466 \\
\hline & & & & & & & & & & & & & 15,9119 & 1 \\
\hline & & & & & & & & & & & & & \multicolumn{2}{|c|}{$\lambda \max =12,3921$} \\
\hline
\end{tabular}

Legend: 1 - castle, 2 - playing field, 3 - areas for horsemanship, 4-sacral buildings, 5 - cross and calvary, 6 cultural event, 7 - museum, 8 -pilgrimage place, 9 -forest pantheon, 10 - specific sport areas, 11 - sport events, 12 - palace; GM-geometrical mean, WGM - weighted geometrical mean 
Areas of high and medium cultural-historical potential are in study area considerably fragmented (Fig. 4). An important area where the focus of significant amount of cultural and historical elements is situated is especially Křtiny, Blansko, Olšovec pond in Jedovnice and Vranov. Individual indicators of cultural-historical potential are placed separately therefore it is not possible to aggregate significantly the value in the reference unit and thus increase its potential.
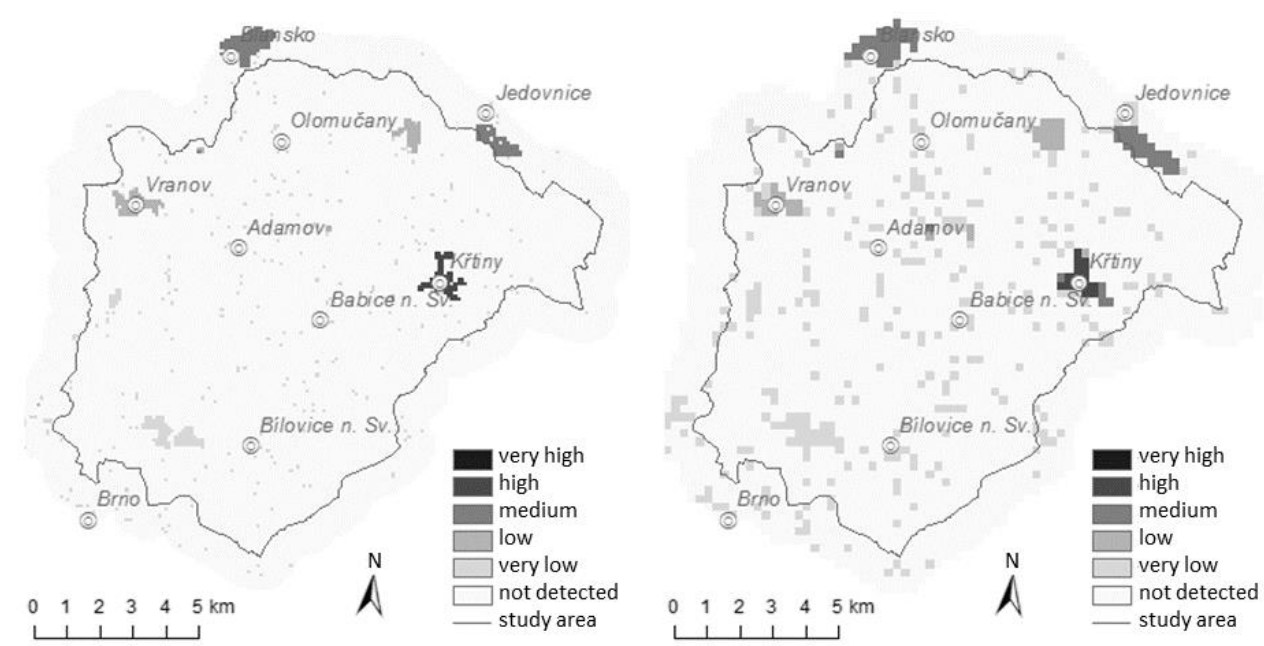

Fig. 4. Cultural-historical potential (left - grid with $100 \mathrm{~m}$ resolution, right - grid with $250 \mathrm{~m}$ resolution).

\subsection{Area usability for tourism development}

In terms of usability study area can be assessed only through four indicators information office, shops, catering and accommodation facilities. Weighing preference is documented by Table 6.

Table 6. Saaty matrix for weights setting within Usability for tourism development.

\begin{tabular}{|c|c|c|c|c|c|c|}
\hline & 1 & 2 & 3 & 4 & GM & WGM \\
\hline 1 & 1 & 4 & 3 & 2 & 2,2134 & 0,4632 \\
\hline 2 & $1 / 4$ & 1 & $1 / 3$ & $1 / 3$ & 0,4082 & 0,0854 \\
\hline 3 & $1 / 3$ & 3 & 1 & $1 / 2$ & 0,8409 & 0,176 \\
\hline 4 & $1 / 2$ & 3 & 2 & 1 & 1,3161 & 0,2754 \\
\hline & & & & & 4,7786 & 1 \\
\hline & & & & & \multicolumn{2}{|c|}{$\lambda \max =4,075$} \\
\hline
\end{tabular}

Legend: 1 - information office, 2 - shops, 3 - catering facilities, 4 -accommodation facilities; GM-geometrical mean, WGM - weighted geometrical mean 
Spot concentration of individual indicators seems to be clear in partial results (Fig. 5). The most prominent sites are near Brno, Jedovnice, Adamov, Bílovice nad Svitavou, Křtiny and Vranov although first two mentioned municipalities are already beyond the area of interest.
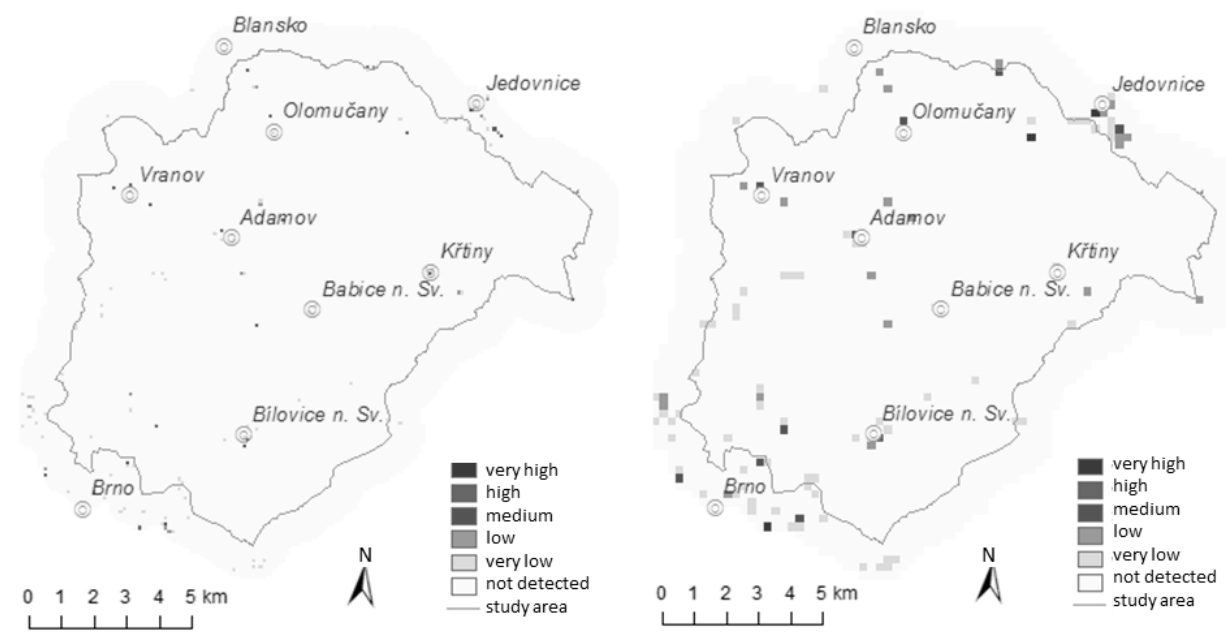

Fig. 5. Usability for tourism development (left - grid with $100 \mathrm{~m}$ resolution, right - grid with $250 \mathrm{~m}$ resolution).

\subsection{Area accessibility for tourism development}

Accessibility for tourism development has been achieved by assessing six indicators with weights derived in Table 7.

Table 7. Saaty matrix for weights setting within Accessibility for tourism development.

\begin{tabular}{|c|c|c|c|c|c|c|c|c|}
\hline & 1 & 2 & 3 & 4 & 5 & 6 & GM & WGM \\
\hline 1 & 1 & $1 / 2$ & $1 / 3$ & $1 / 5$ & $1 / 3$ & 3 & 0,5673 & 0,0713 \\
\hline 2 & 2 & 1 & $1 / 3$ & $1 / 4$ & $1 / 2$ & 3 & 0,6813 & 0,0857 \\
\hline 3 & 3 & 3 & 1 & $1 / 3$ & 2 & 5 & 1,7627 & 0,2217 \\
\hline 4 & 5 & 4 & 3 & 1 & 3 & 5 & 3,1072 & 0,3907 \\
\hline 5 & 3 & 5 & $1 / 2$ & $1 / 3$ & 1 & 5 & 1,5234 & 0,1916 \\
\hline 6 & $1 / 3$ & $1 / 3$ & $1 / 5$ & $1 / 5$ & $1 / 5$ & 1 & 0,3101 & 0,039 \\
\hline & & & & & & & 7,9521 & 1 \\
\hline & & & & & & & \multicolumn{2}{|c|}{$\lambda \max =6,4504$} \\
\hline
\end{tabular}

Legend: 1 -bus stops, 2 - other way, 3 -cycle paths, 4 -road, 5 -tourist trials, 6 - railway station; GMgeometrical mean, WGM-weighted geometrical mean 
Accessibility for tourism development is in study area at very high level. Individual settlements are mutually interconnected by relatively dense network of roads. Significant impacts on the results have roads and paths interlacing forest land (Fig. 6).

The existence of hiking and biking trails bring the area significant added value because cyclists and walkers are persons who use them regularly. In addition, the area is served by a quality bus service as evidenced by the relatively large number of present bus stops. Comfort transport is also ensured by railways and visitors from distant regions can easily get to the region of SFE MF Krrtiny.
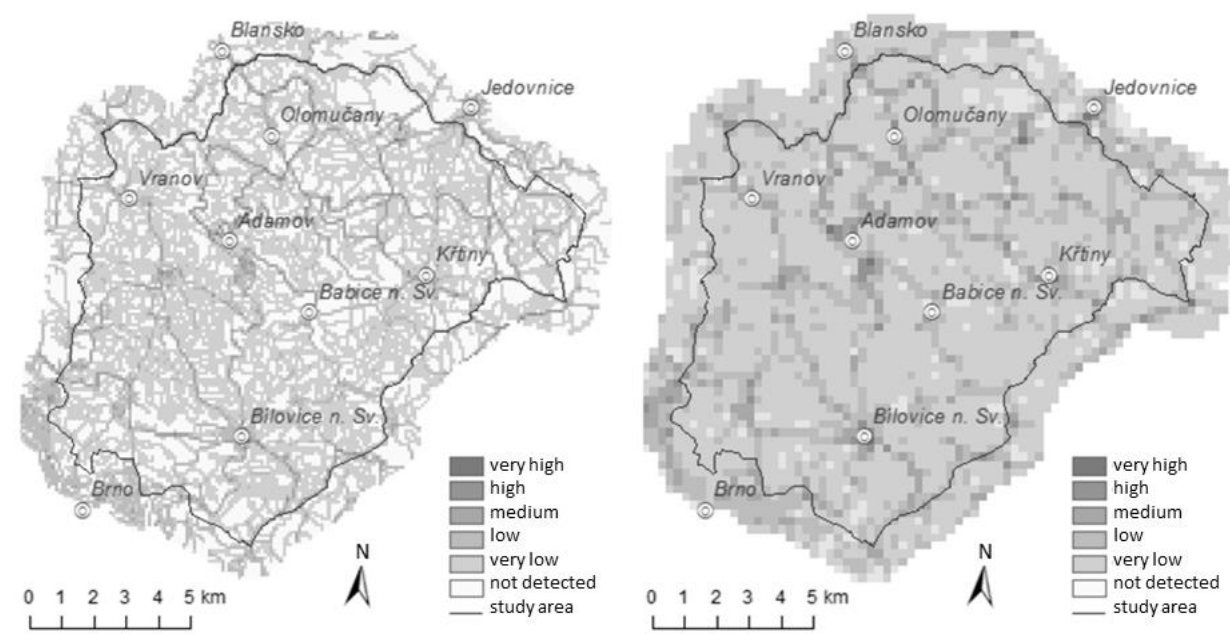

Fig. 6. Area accessibility for tourism development (left - grid with $100 \mathrm{~m}$ resolution, right - grid with $250 \mathrm{~m}$ resolution).

\section{RESULTS}

\subsection{Localization and realization potential of tourism}

Localization assumptions were calculated as sum of values of natural and culturalhistorical potential. Although these two assumptions were considered as equivalent partial results show that natural potential dominates over cultural-historical potential (Fig. 7).

The explanation seems to be quite logical because in terms of actual cultural-historical potential the study area does not reach such favourable results as in case of natural potential. Higher values of localization assumptions were identified especially in very attractive areas around Krrtiny and Adamov and around the Olšovec pond in Jedovnice. 


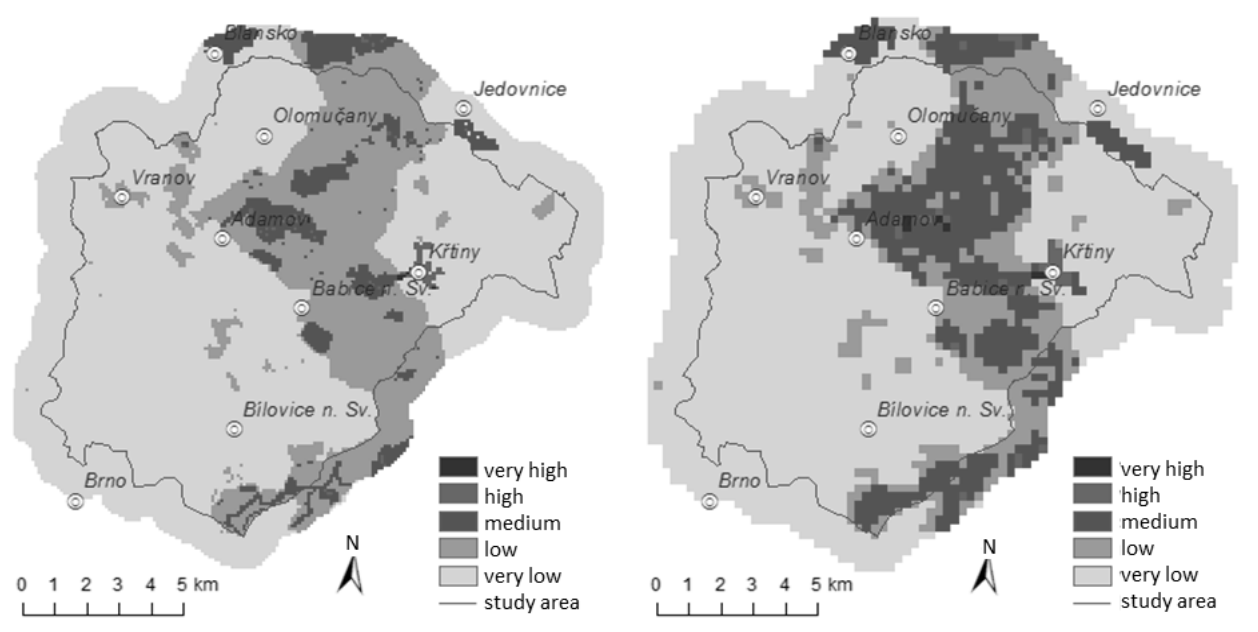

Fig. 7. Localization assumptions of tourism potential (left - grid with $100 \mathrm{~m}$ resolution, right - grid with $250 \mathrm{~m}$ resolution).

Realization assumptions have been derived as the sum of values of usability and accessibility of the study area (Fig. 8). A dense network of ways, footpaths and roads is further enhanced by the appearance of facilities of the material-technical base. Realization assumptions are in many areas at moderate to very high levels. For possible future development of tourism potential it is a positive finding, as it is well placed to make itself affordable and widely accessible for many potential visitors.
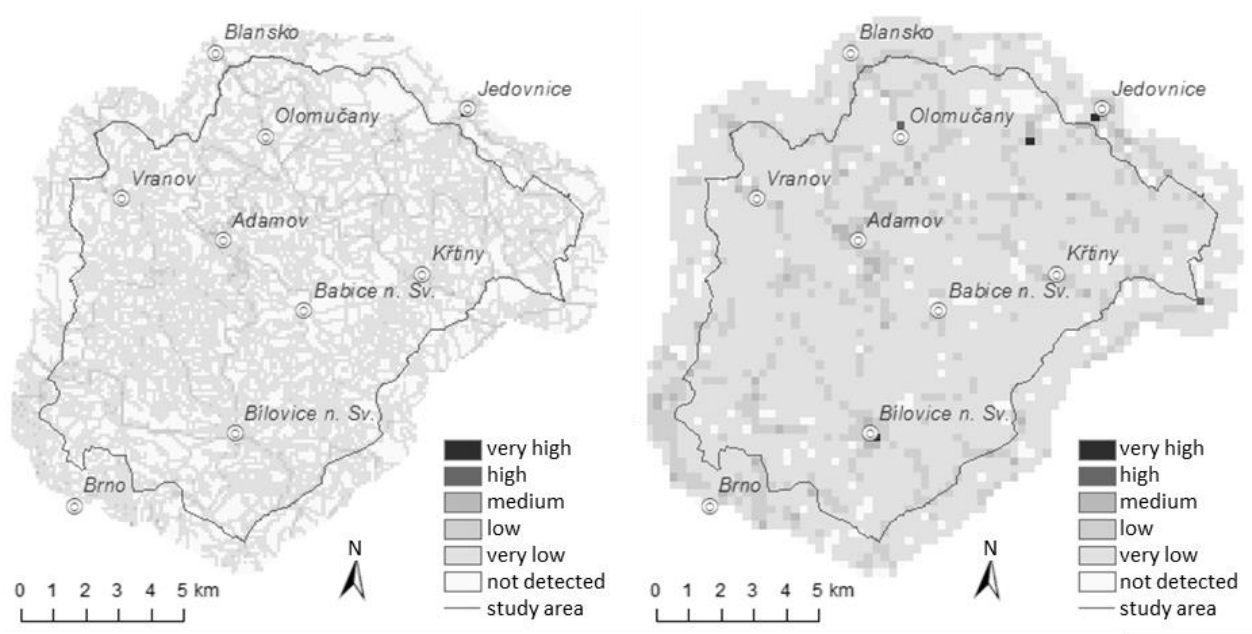

Fig. 8. Realization assumptions of tourism potential (left - grid with $100 \mathrm{~m}$ resolution, right - grid with $250 \mathrm{~m}$ resolution). 

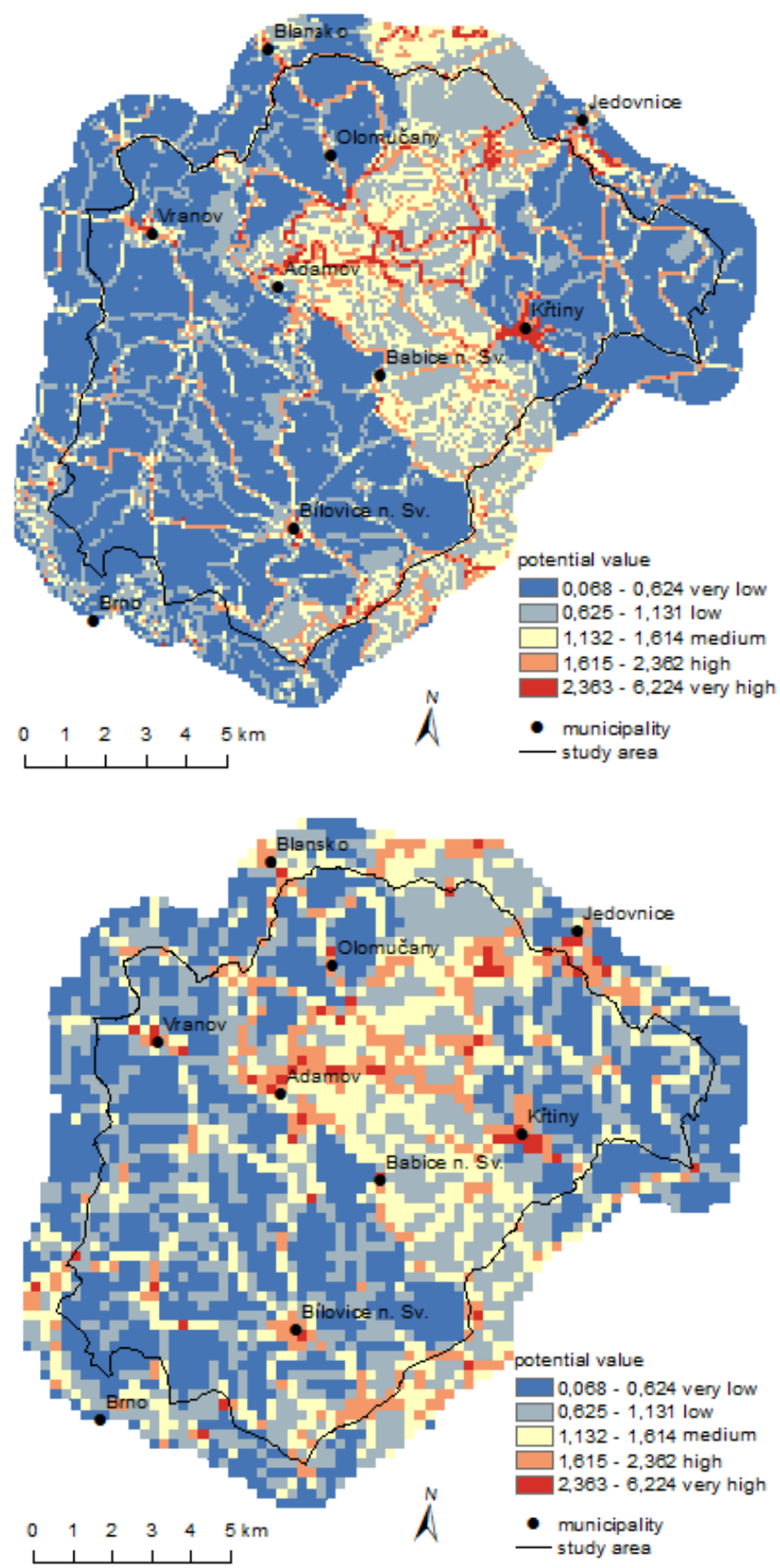

Fig. 9. Tourism potential (top - grid with $100 \mathrm{~m}$ resolution, bottom - grid with $250 \mathrm{~m}$ resolution). 


\subsection{Final tourism potential}

Final tourism potential was derived as the sum of localization and realization assumptions reclassified by Natural breaks algorithm into five classes. Largely realization assumptions prevail while individual natural, cultural-historical potential is supressed. According to results (Fig. 9), it is possible to point out a few regions characterized by medium or high tourism potential. In general, they can be found around settlements. Although it might have seemed that tourism potential of the study area is generally very low or low, SFE MF Krrtiny offers countless tourist attractions but their existence unfortunately disappears in the final model under indicators with higher weight.

\section{CONCLUSION REMARKS}

Tourism potential assessment using GIS approaches may be conducted within chosen reference unit or calculated inside administrative regions. Both approaches have their advantages. In case of administrative units we can get results comparable among municipalities but not informing about details position. Described proposal uses chosen reference units with different resolution to highlight needed details. On the other hand we can also get initial results for regionalization procedure. Further, we can discuss assessing procedure even if selection of indicators and weighting preference are supported by questionnaire survey. Besides many others published assessing methods, presented method tries to capture local scale based on well-known information about the territory.

Tourism potential cannot be evaluated solely only on the basis of described methodology proposal, even though input indicators were confronted with a slightly subjective evaluation. Although proposed tourism potential is not $100 \%$ objective and each person distinguishes the importance of attributes within tourism industry individually, for tourism development it is necessary to inform visitors about areas which may be the most interesting. In case study area it is evident that highly valuated areas can be find around municipalities and along connections between them.

According to proposed methodology accessibility plays dominant role. The most significant area from tourist potential point of view is bordered by the line connecting Jedovnice, Adamov, Babice nad Svitavou and Křtiny. Based on field survey it is also apparent, that not all mentioned municipalities (eg. Adamov) have their strong tourist potential in popular tourist attractions but in incidental infrastructure.

Proposed models of partial potentials may have a wide range of applications. Firstly it offers to produce an electronic photo book including selected objects representing tourist attractions categorized into several relevant categories. Each object would have been completed with a brief description and its position on the map. Sufficient information is nowadays a key factor not only in tourism but also in other issues related to the development of regions. Basically, if potential visitors are informed about the existence of attractive areas it is highly likely that they will visit them.

\section{R E F E R E N C E S}

Bernadóa, O., Bigorra, A., Pérez, Y., Orellana, A., Russob, A. P. \& Clave, S. A. (2013) Analysis of tourist behaviour based on the tracking data collected by GPS. Geographic Information Systems: Concepts, Methodologies, Tools, and Applications (pp. 1100-1119). Hershey, PA: Information Science Reference. 
Bína, J. (2010) Aktualizace potenciálu cestovního ruchu v České republice. Závěrečná zpráva. [Online] Available from: from: http://www.uur.cz/images/uzemnirozvoj/cestovniruch/potencialCR/PotencialCR-text.pdf.

Butler, R.W. (1993) Tourism - an evolutionary perspective, in Tourism and Sustainable Development: Monitoring, Planning, Managing, eds. J. G. Nelson, R.W. Butler, G. Wall. Waterloo, Ontario: University of Waterloo, pp. 27-44.

Butler, R.W. (1999) Sustainable tourism: A state-of-the-art review. Tourism geographies, 1, 7-25. [Online] Available from: doi 10.1080/14616689908721291.

Clarke, J. (1997) A Framework of Approaches to Sustainable Tourism. Journal of Sustainable Tourism, 5, pp. 224-233. [Online] Available from: doi 10.1080/09669589708667287.

Coccossis, H. (1996) Tourism and sustainability: Perspectives and implications, in Sustainable Tourism? European Experiences, eds. G. K. Priestley, J. A. Edweards, H. Coccossis. Wallingford, Oxford: CAB International, pp. 1-21.

Gobster, P. H, Gimblett, H. R. \& Kelley, B. B. (1987) Modelling forest recreational policy alternatives: a geographic information systems approach. In Proceedings of GIS 87. Falls Church: American Society for Photogrammetry and Remote Sensing, pp. 101-111.

Hrala, V. (2002) Geografie cestovního ruchu. Praha: Idea servis.

Klapka, P., Nováková, E. \& Frantál, B. (2008) Metodologické př́stupy k hodnocení potenciálu cestovního ruchu území. In Miscellanea Geographica. Plzeň: Západočeská univerzita, pp. 169174.

Kliskey, A. D. (2000) Recreation terrain suitability mapping: a spatially explicit methodology for determining recreation potential for resource use assessment. Landscape and Urban planning 52, 33-43. [Online] Available from: doi 10.1016/S0169-2046(00)00111-0

Krippendorf, J. (1980) Marketing im Fremdenverkehr. Las Vegas: Lang.

Levinsohn, A., Langford, G., Rayner, M., Rintoul, J. \& Eccles, R. (1987) A micro-computer based GIS for assessing recreation suitability. In Proceedings of GIS 87. Falls Church: American Society for Photogrammetry and Remote Sensing, pp. 739-747.

Lyle, J. \& Stutz, F. P. (1983) Multivariate Statistical methods: A Primer. London: Chapman and Hall.

McHarg, I. (1969) Design with nature. New York: The Natural History Press: Garden City.

Mikulec, J. \& Antoušková, M. (2011) Využití GIS (geografické informační systémy) v turismu (CHKO Kokořinsko). Czech Hospitality and Tourism Papers, 13, 93-114.

Pásková, M. (2014) Udržitelnost rozvoje cestovního ruchu. Hradec Králové: Gaudeamus.

Pásková, M. \& Zelenka, J. (2002) Výkladový slovník cestovního ruchu. Praha: Linde Praha.

Pokladníková, M. (2015) Potenciál cestovního ruchu ŠLP Masarykův les Křtiny. Bachelor thesis. Brno: Mendel university in Brno.

Ruda, A. (2010) Contribution to assessement of the tourism impact on landscape. Acta Universitatis Carolinae Geographica, 45, 61-74.

Ruda, A. (2014) Hodnocení a vizualizace vlivu cestovního ruchu na krajinu Nízkého Jeseníku. Brno: Mendelova univerzita v Brně.

Sharpley, R. (2000) Tourism and Sustainable Development: Exploring the Theoretical Divide. Journal of Sustainable Tourism, 8, 1-19. [Online] Available from: doi 10.1080/09669580008667346.

Slpkrtiny.cz. (2008). Školní lesní podnik ML Křtiny [Online] Available from: http://www.slpkrtiny.cz/slp-krtiny/o-nas.

Vystoupil, J., Holešinská, A., Kunc, J. \& Šauer, M. (2006) Teoreticko-metodologické př́stupy k tvorbě rajonizace cestovního ruchu v České republice. Ekonomická revue cestovného ruchu, 41, 105-117. 